Terbit online pada laman : http://teknosi.fti.unand.ac.id/

\title{
Pemetaan Web-GIS untuk Panti Asuhan Kota Padang dengan Fitur Pendaftaran Aktivitas Sosial
}

\author{
Haris Suryamen $^{a}$, Aulia Ayu Lukman ${ }^{a}$, Fajril Akbar $^{a}$ \\ a Jurusan Sistem Informasi Fakultas Teknologi Informasi Universitas Andalas
}

\section{INFORMASI ARTIKEL}

Sejarah Artikel:

Diterima Redaksi: 15 Juli 2019

Revisi Akhir: 30 Desember 2019

Diterbitkan Online: 16 Januari 2020

\section{KATA KUNCI}

Panti Asuhan,

Sistem Informasi Geografis,

Rute transportasi

KORESPONDENSI

E-mail: haris.suryamen@fti.unand ac.id *

\begin{abstract}
A B S S T R A C $\mathbf{C}$
Panti asuhan adalah tempat untuk anak yatim piatu, anak yatim, serta anak-anak dari keluarga kurang mampu dan lainnya dapat menetap. Oleh sebab itu, panti asuhan juga banyak dilakukan oleh aktivitas sosial. Dinas Sosial Kota Padang menyatakan pada tahun 2018 terdapat 25 panti asuhan yang telah terdaftar. Untuk melaksanakan aktivitas sosial di panti asuhan, biasanya masyarakat langsung mendatangi panti asuhan yang dituju. Untuk melakukan aktivitas social nya terkadang perlu datang berkali-kali ke panti asuhan untuk kepastian dan pengurusan administrasi kegiatan sosial yang akan dilaksanakan. Dengan penerapan sistem informasi sebagai penyediaan informasi yang dapat digunakan melalui perangkat webGIS (Web Geographic Information System) maka semua permasalahan tersebut dapat diatasi. Pada penelitian ini dikembangkan pemetaan berbasi webGIS untuk Panti Asuhan Kota Padang yang dilengkapi dengan pendaftaran aktivitas sosial. Penelitian ini mengadopsi model pengembangan perangkat lunak Waterfall. Aplikasi ini telah diimplementasikan menggunakan bahasa pemrograman PHP dan Javascript. Hasil pengujian yang dilakukan oleh 5 orang pengguna menunjukkan bahwa sistem yang dibangun telah sesuai rancangan fungsional yang direncanakan.
\end{abstract}

\section{PENDAHULUAN}

Panti asuhan merupakan tempat dimana anak yatim, anak yatim piatu, anak-anak dari keluarga kurang mampu dan sebagainya dapat tinggal, tumbuh, dan berkembang selayaknya anak pada umumnya. Berdasarkan data dari Dinas Sosial Kota Padang pada tahun 2018, ada 25 buah panti asuhan yang sudah terdaftar[1]. Panti asuhan menjadi salah satu tempat untuk melakukan aktivitas sosial. Untuk melakukan kegiatan sosial di panti asuhan, biasanya masyarakat akan mengunjungi panti asuhan untuk mendapatkan informasi terkait aktivitas sosial yang ingin dilakukan. Masyarakat yang ingin melakukan aktivitas sosial di panti asuhan harus datang berkali-kali untuk melakukan koordinasi kegiatan [2]. Proses ini membutuhkan waktu yang lama untuk melakukan koordinasi disetiap panti asuhan yang berada di Kota Padang. Masyarakat juga banyak tidak mengetahui lokasi panti asuhan terdekat.
Permasalahan tersebut dapat diatasi dengan penerapan sistem informasi yang mudah diakses pengguna dan berbasis lokasi yang dikenal sebagai webGIS (web Geographic Information System). Dengan sistem informasi geografis berbasis web, pengguna dapat mengetahui lokasi dan juga dapat melakukan pencarian panti asuhan yang ada di Kota Padang berbasis lokasi yang disediakan oleh Google Maps. Sistem yang akan dibangun ini bertujuan untuk memberikan informasi persebaran panti asuhan di Kota Padang, dan informasi mengenai panti asuhan tersebut. Selain itu, pada sistem ini pengguna bisa mendaftarkan kegiatan sosial apa yang ingin dilakukan di panti asuhan yang dipilih.

Beberapa penelitian telah dilakukan dalam pemanfaatan sistem informasi untuk panti asuhan [3][4]. Pemanfaatan sistem informasi geografis juga menjadi solusi bagi pemetaan berbagai aspek seperti kelompok tani [5], sebaran rumah tangga miskin di Bukittinggi [6] dan pengelolaan desa [7]. Pemanfaatan sistem 
informasi juga telah banyak manfaat bagi dunia pariwisata terutama pendaftaran berbagai aktivitas wisata [8]. [9] telah mengkaji penggunaan sistem informasi geografis untuk pengelolaan fasilitas umum di Singapura. WebGIS juga telah diimplementasikan dalam pemetaan hewan liar di Iran [10] dan dijadikan alat bantu untuk analisis bagi perlindungan kesehatan manusia dari dampak asap kebakaran di Amerika Serikat [11. Pemanfaatan WebGIS juga telah diimplementasikan dalam dunia penddikan [12].

Oleh karena itu didapatkan rumusan bahwa bagaimana menerapkan sebuah sistem informasi geografis panti asuhan di Kota Padang yang bertujuan untuk untuk membantu menyelesaikan masalah pencarian lokasi panti asuhan, informasi mengenai panti asuhan, dan pendaftaran kegiatan sosial pada panti asuhan di Kota Padang.

\section{METODE}

Pengumpulan data dilakukan dengan cara observasi kesetiap lokasi untuk mengambil titik koordinat dan informasi panti asuhan yang ada di Kota Padang. Pengumpulan data juga dilakukan dengan cara mendapatkan dokumen dari panti asuhan di Kota Padang ke Dinas Penanaman Modal Dan Pelayanan Terpadu Satu Pintu Kota Padang. Wawancara dengan pengguna juga dilakukan dengan cara meminta informasi yang terkait dengan panti asuhan kepada pemilik tempat atau pengurus sebagai narasumber.

Pengembangan perangkat lunak pemetaan panti sosial Kota Padanf dengan fitur pendaftaran aktivitas sosial menggunakan model Waterfall [13]. Pada tahap analisis dan definisi persyaratan menganalisis kebutuhan sistem termasuk proses bisnis yang berjalan. Hasil dari analisis ini dirumuskan dengan kebutuhan fungsional pada sistem. Pada tahapan perancangan sistem dan perangkat lunak meliputi perancangan arsitektur sistem, perancangan basis data, perancangan user interface, dan perancangan proses. Pada tahapan implementasi yang dilakukan adalah menerjemahkan rancangan pada tahap sebelumnya menjadi kode-kode program. Pada tahapan pengujian dilakukan . Pengujian dilakukan dengan metode blackbox testing, yaitu dengan cara input data dan melihat output $\neg$-nya. Pengujian dilakukan oleh 5 orang penguji, yaitu satu orang dari pihak Dinas Sosial Kota Padang dan empat orang pengguna umum dengan cara menjalankan fungsional yang ada secara langsung untuk memastikan fungsional yang telah dibangun itu berjalan sesuai fungsinya.

\section{HASIL}

\section{Analisis Sistem}

Pada tahap analisis sistem pada aplikasi ini berisikan mengenai BPMN (Business Process Modelling Notation). Proses pendaftaran kegiatan panti asuhan ini didapatkan berdasarkan hasil dari wawancara pada beberapa panti asuhan yang terdaftar pada Dinas Sosial wilayah kota Padang dapat dilihat pada Gambar 1.

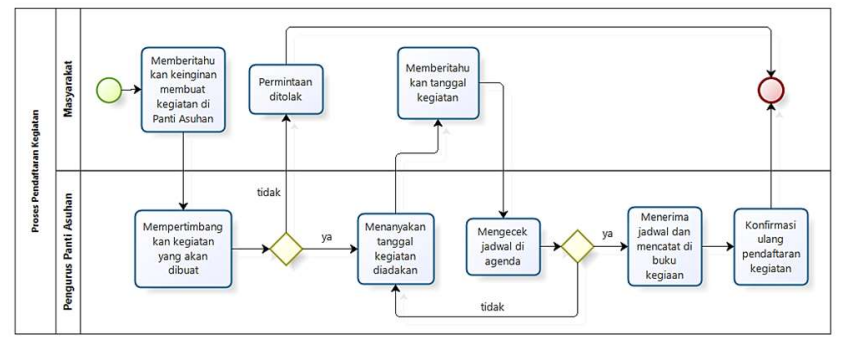

Gambar 1. BPMN proses pendaftaran kegiatan sosial di panti asuhan

Berdasarkan analisis yang telah dilakukan pada proses pendaftaran kegiatan sosial di panti asuhan, maka penulis mengusulkan proses baru yang dapat dilihat pada Gambar 2 .

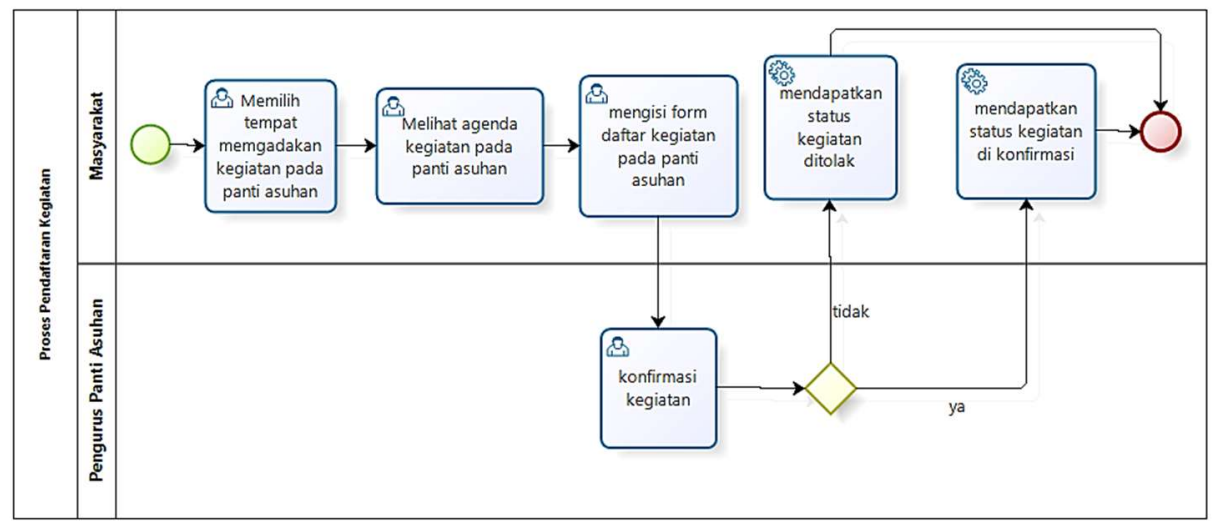

Gambar 2. BPMN proses pendaftaran kegiatan sosial di panti asuhan

\section{Analisis Kebutuhan}

Tahap analisis kebutuhan pada aplikasi ini berisikan tentang kebutuhan fungsional dan non-fungsional sistem dan hasil analisis kebutuhan digambar use case diagram, context diagram, data flow diagram. Kebutuhan fungsional pengguna terhadap sistem ini merupakan kegiatan yang bisa dilakukan pengguna oleh sistem, adalah sebagai berikut.

1. Fungsi login.

2. Fungsi melihat posisi pengguna saat menggunakan sistem.

3. Fungsi mencari posisi manual pengguna di peta.

4. Fungsi mencari panti asuhan disekitar posisi pengguna. 
5. Fungsi menampilkan rute Google Maps dari posisi pengguna ke tempat panti asuhan yang dituju.

6. Fungsi menampilkan semua panti asuhan di peta.

7. Fungsi mencari panti asuhan berdasarkan nama.

8. Fungsi mencari panti asuhan berdasarkan kecamatan.

9. Fungsi mencari panti asuhan berdasarkan fasilitas.

10. Fungsi melihat informasi detail panti asuhan.

11. Fungsi melihat list panti asuhan.

12. Fungsi melihat kalender kegiatan pada panti asuhan.
13. Fungsi mengisi form daftar kegiatan pada panti asuhan.

14. Fungsi melihat status kegiatan.

Context diagram pada aplikasi ini terdiri dari empat entitas yaitu pengguna, pengurus, admin, dan Google Maps. Context diagram analisis dan perancangan pemetaan panti sosial Kota Padang dengan fitur pendaftaran aktivitas sosial dapat dilihat pada Gambar 3.

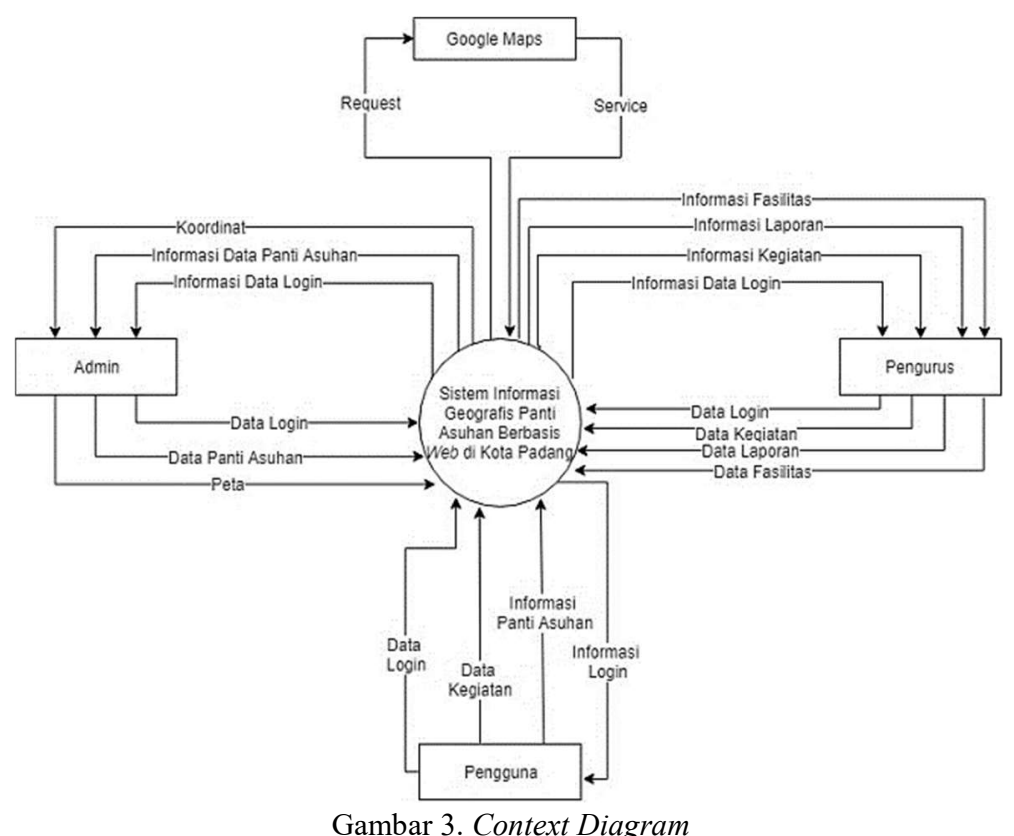

\subsubsection{Kebutuhan Data Spasial}

Data spasial yang digunakan pada pemetaan panti sosial Kota Padanf dengan fitur pendaftaran aktivitas sosial adalah Base Maps, dengan menggunakan Google Maps. Base Maps ini digunakan sebagai peta dasar dalam pembangunan Sistem Informasi Geografis Panti Asuhan di Kota Padang Berbasis Web. Layer batas kecamatan dalam bentuk polygon. Layer ini adalah digitasi dari kecamatan se-Kota Padang. Layer panti asuhan dalam bentuk polygon. Layer ini adalah digitasi panti asuhan di Kota Padang.

\subsubsection{Rancangan Basis Data}

Basis data dari aplikasi ini menggunakan PostgreSQL yang berekstensi PostGIS dan terdiri dari 8 tabel, yaitu terdiri dari tabel kegiatan, tabel detail_keg, tabel panti, tabel data_user, tabel fasilitas, tabel detail_fas, tabel kecamatan, dan tabel admin_master. Tabel-tabel tersebut ada yang memiliki relasi dan ada yang tidak. Setiap tabel memiliki field dengan tipe data sesuai kebutuhan dan primary key. Rancangan basis data dari pemetaan panti sosial Kota Padang dengan fitur pendaftaran aktivitas sosial bisa dilihat pada Gambar 4 .

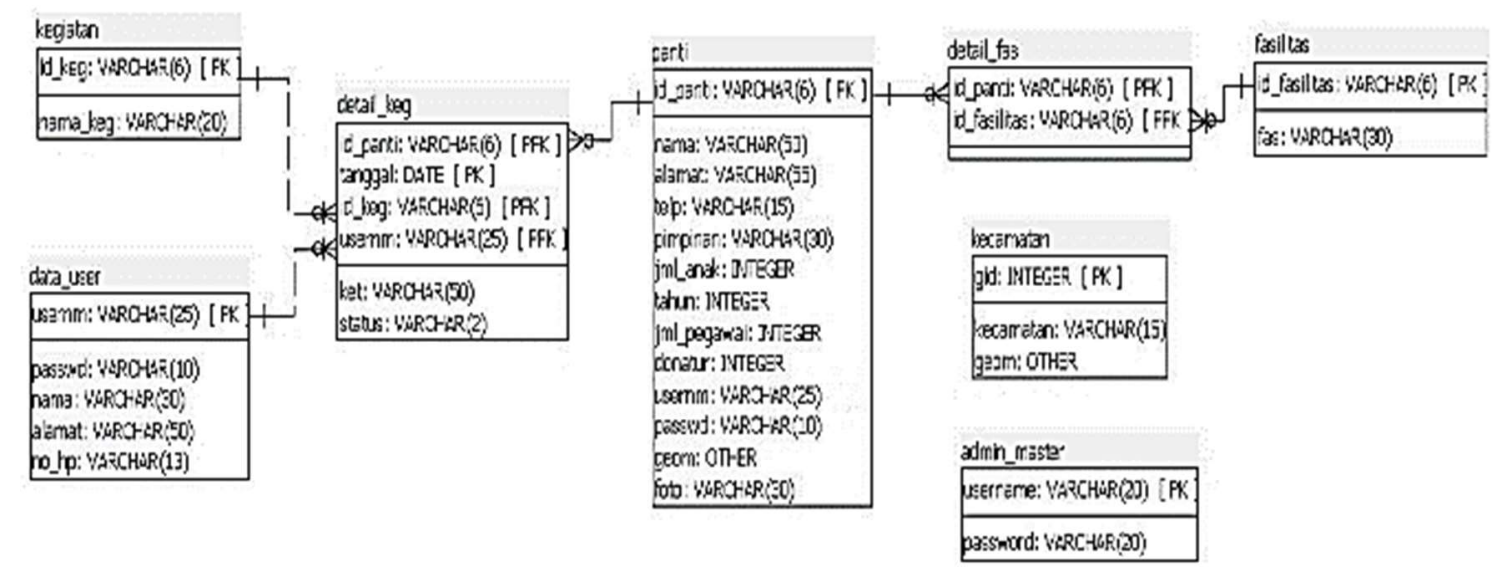

Gambar 4. Rancangan basis data SIG Panti Asuhan di Kota Padang 


\subsubsection{Rancangan Proses}

Perancangan proses digunakan untuk menggambarkan interaksi dan aktifitas penguna dengan sistem berdasarkan fungsional sistem. Skenario daftar kegiatan menggambarkan urutan aktivitas untuk mendaftarkan kegiatan yang ingin dilakukan pada panti asuhan yang diinginkan. Skenario ini dapat dilihat pada Tabel 1.

Tabel 1. Skenario daftar kegiatan

\begin{tabular}{|c|c|}
\hline Use Case & Daftar Kegiatan \\
\hline $\begin{array}{l}\text { Participating } \\
\text { Actor }\end{array}$ & Pengguna \\
\hline \multirow[t]{3}{*}{ Flow of Event } & $\begin{array}{l}\text { 1. Pengguna memilih Form Daftar } \\
\text { Kegiatan pada side bar }\end{array}$ \\
\hline & $\begin{array}{l}\text { 2. Pengguna mengisikan data seperti } \\
\text { nama panti asuhan, jenis kegiatan, } \\
\text { tanggal, dan keterangan }\end{array}$ \\
\hline & $\begin{array}{l}\text { 3. Pengguna memilih tombol Submit } \\
\text { 4. Sistem menampilkan Home }\end{array}$ \\
\hline Entry Condition & Pengguna telah login \\
\hline Exit Condition & $\begin{array}{l}\text { Pengguna telah mendaftarkan kegiatan } \\
\text { yang ingin dilakukan }\end{array}$ \\
\hline
\end{tabular}

Skenario mencetak laporan kegiatan menggambarkan urutan aktivitas untuk mencetak laporan kegiatan yang diinginkan. Skenario ini dapat dilihat pada Tabel 2.

Tabel 2. Skenario daftar kegiatan

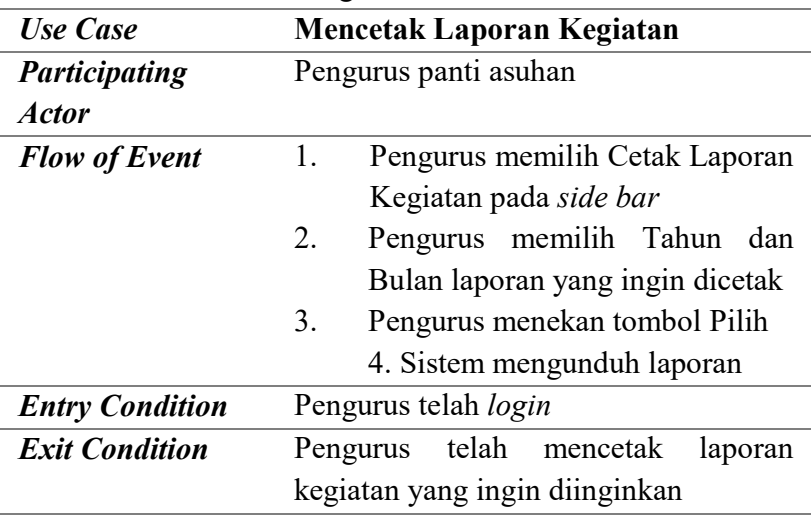

\section{Implementasi Sistem}

Implementasi sistem yang dibuat adalah implementasi basis data, User Interface, dan implementasi proses. Implementasi pemetaan panti sosial Kota Padanf dengan fitur pendaftaran aktivitas sosial untuk basis data yang digunakan adalah PostgreSQL v10.2.4 beserta ekstensi PostGIS v10.2.4, dan tampilan User Interface dibangun dengan menggunakan library CSS dari Bootstrap untuk web serta program menggunakan bahasa pemrograman PHP, JavaScript.. Implementasi perangkat lunak dapat diakses pada alamat URL https://panti-pdg.herokuapp.com.

\section{PEMBAHASAN}

Pengujian pemetaan panti sosial Kota Padanf dengan fitur pendaftaran aktivitas sosial dilakukan menggunakan metode blackbox testing, yaitu dengan mengamati masukan yang diberikan kepada sistem dan luaran yang dihasilkan oleh sistem.
Blackbox testing merupakan metode pengujian yang penilaiannya dilakukan terhadap sebuah aplikasi bukan terletak pada spesifikasi logika atau fungsi aplikasi tersebut, tetapi melalui input dan output. Hasil pengujian dikatakan benar, apabila luaran yang dihasilkan oleh sistem sama dengan yang dirancang dan jika tidak sama dengan kebutuhan fungsional sistem maka dapat dinyatakan tidak berhasil dan perlu dilakukan perbaikan.

\section{Pengujian Mengisi Form Daftar Kegiatan}

Pengujian yang dilakukan adalah mengisi form daftar kegiatan. Berdasarkan hasil pengujian pengguna telah mendaftarkan kegiatan di panti asuhan yang diinginkan dan dengan status "belum di konfirmasi". Prosedur pengujian tersebut dapat dilihat pada Tabel 3. Hasil pengujian manual dapat dilihat pada Gambar 5. Hasil pengujian pada aplikasi dapat dilihat pada Gambar 6 . Untuk melihat status pendaftaran bisa dilihat pada Gambar 7.

Tabel 3 Prosedur pengujian mengisi form daftar kegiatan

\begin{tabular}{ll}
\hline Aksi & Pengguna memilih menu Form Daftar \\
& Kegiatan kemudian mengisi data yaitu \\
& memilih Panti Asuhan Wira Lisna, \\
& memilih jenis kegiatan Bakti Sosial, \\
& memilih tanggal 01/12/2018, dan \\
& mengosongkan Keterangan. \\
\hline Ekspetasi & Sudah mendaftarkan kegiatan di Panti \\
& Asuhan Wira Lisna \\
\hline Hasil & Sudah mendaftarkan kegiatan di Panti \\
& Asuhan Wira Lisna \\
\hline Kesalahan & Tidak ada \\
\hline Pengujian & Sesuai dengan ekspektasi
\end{tabular}

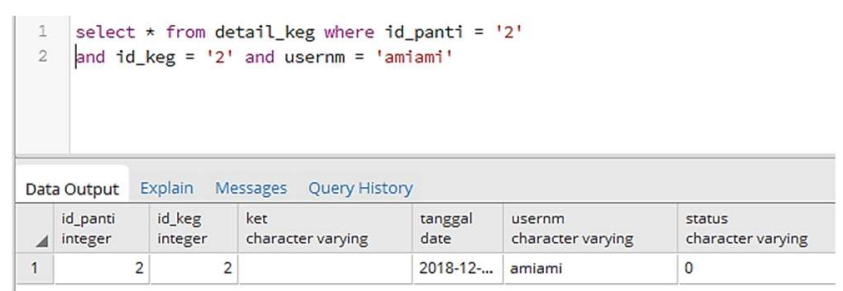

Gambar 5. Pengujian manual mengisi form daftar kegiatan pada database postgresql

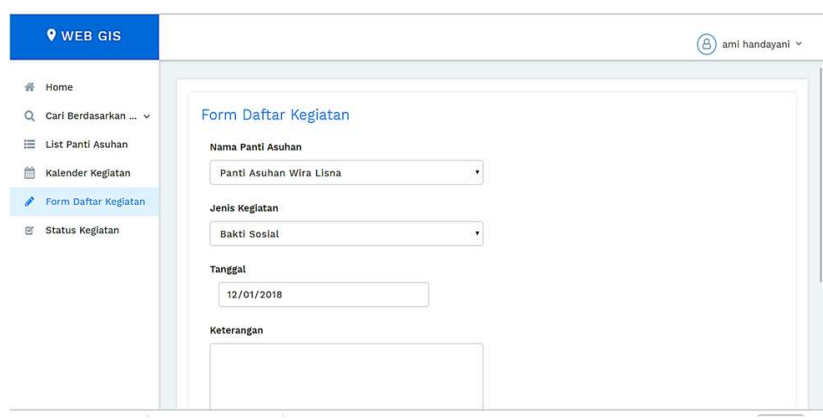

Gambar 6. Hasil pengujian mengisi form daftar kegiatan 
Pengujian Konfirmasi Kegiatan di Panti Asuhan

Pengujian yang dilakukan adalah mengkonfirmasi proses pendaftaran kegiatan di panti asuhan. Pengujian dilakukan oleh pengurus panti asuhan untuk mengetahui bahwa fungsional ini telah sesuai dengan yang dirancang. Prosedur pengujian tersebut dapat dilihat pada Tabel 4. Hasil pengujian manual dapat dilihat pada Gambar 8. Halaman tampilan konfirmasi kegiatan dapat dilihat pada Gambar 9. Hasil pengujian pada aplikasi dapat dilihat pada Gambar 10.

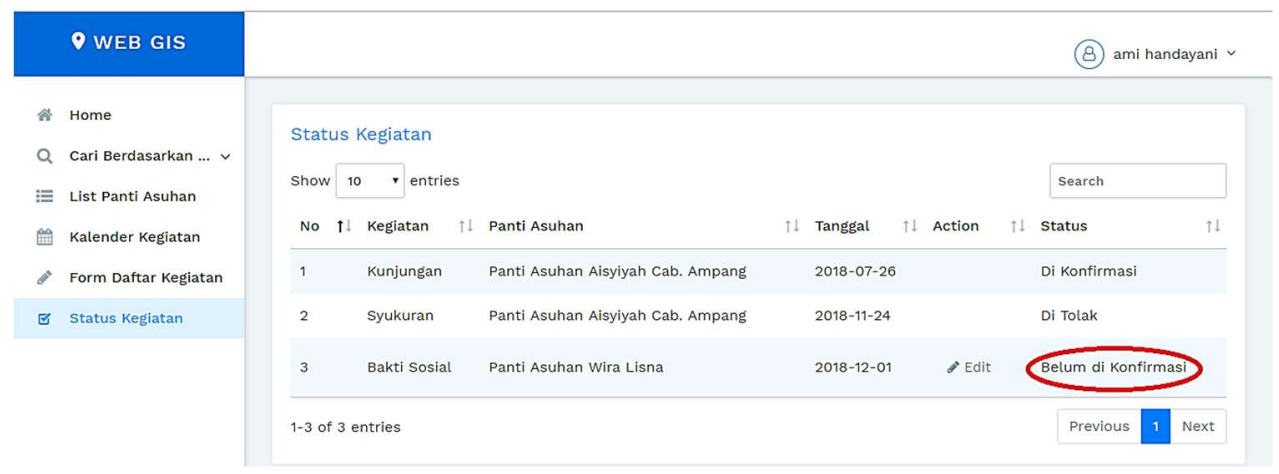

Gambar 7. Status Kegiatan

Tabel 4. Prosedur pengujian konfirmasi kegiatan

Aksi
Pengurus panti asuhan memilih menu Konfirmasi Kegiatan, kemudian pengurus mengkonfirmasi kegiatan dari user "amiami" dengan jenis kegiatan "syukuran" dan pada tanggal 24 November 2018, lalu klik tombol Konfirmasi

\begin{tabular}{cll}
\hline Ekspektasi & $\begin{array}{l}\text { Data pendaftaran kegiatan pada panti } \\
\text { asuhan Aisyiyah Cab. Ampang telah } \\
\text { dikonfirmasi }\end{array}$ \\
\hline Hasil & $\begin{array}{l}\text { Data pendaftaran kegiatan pada panti } \\
\text { asuhan Aisyiyah Cab. Ampang telah } \\
\\
\text { dikonfirmasi }\end{array}$ \\
\hline Kesalahan & Tidak ada \\
\hline Pengujian & Sesuai dengan ekspektasi \\
\hline
\end{tabular}

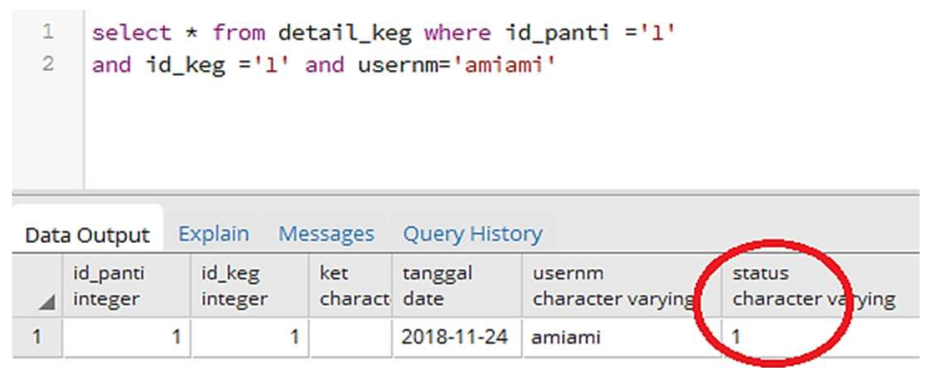

Gambar 8. Pengujian manual konfirmasi kegiatan pada database postgresql

\section{- WEB GIS}

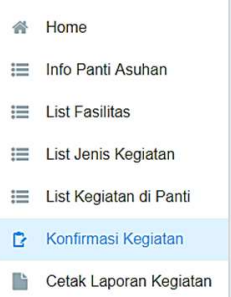

Konfirmasi Kegiatan di Panti Asuhan Aisyiyah Cab. Ampang

Show 10 entries

No $\uparrow$ User $\uparrow 1$ Kegiatan $\uparrow 1$ Tanggal i Action

1 wewe Kunjungan

2 wewe Ulang Tahun

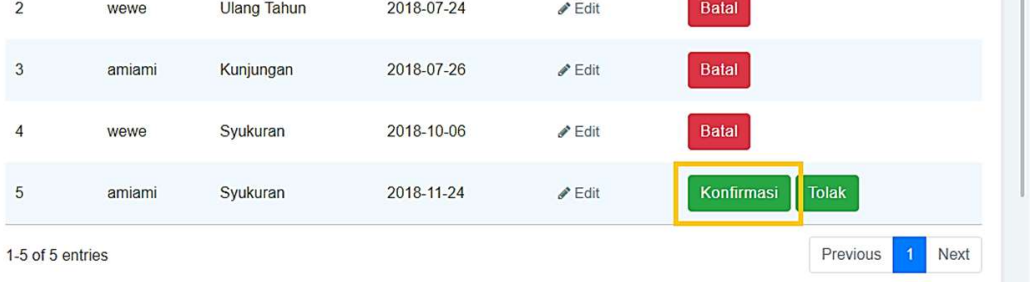

Gambar 9. Tampilan halaman konfirmasi kegiatan 


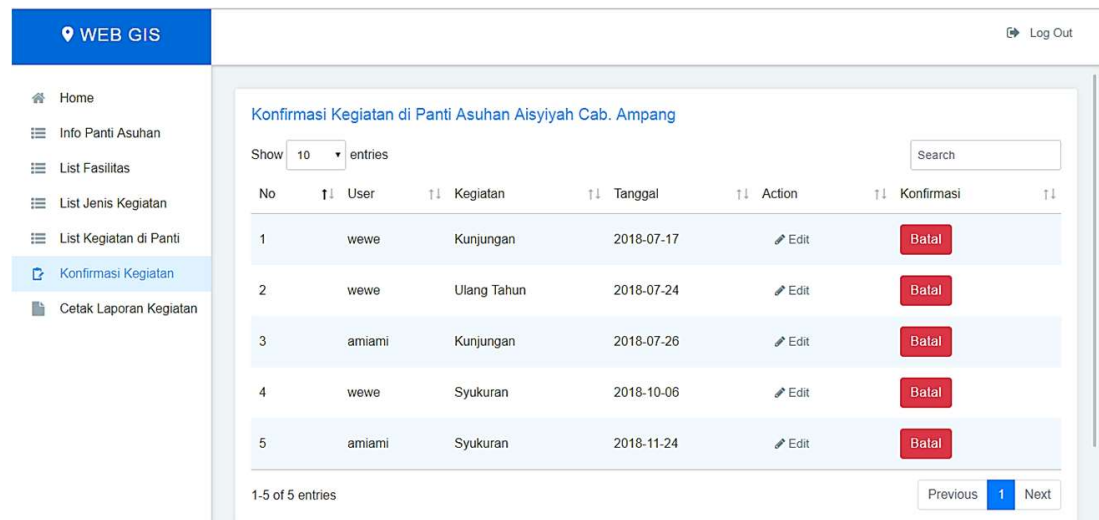

Gambar 10. Hasil pengujian konfirmasi kegiatan di panti asuhan

Sedangkan pengujian mengkonfirmasi proses pendaftaran kegiatan di panti asuhan apabila ditolak dapat dilihat pada Tabel 5. Hasil pengujian manual dapat dilihat pada Gambar 11. Tampilan halaman konfirmasi kegiatan ditolak dapat dilihat pada Gambar 12. Hasil pengujian pembatalan pada konfirmasi kegiatan di panti asuhan dapat dilihat pada Gambar 13.

Tabel 5. Prosedur pengujian konfirmasi kegiatan (ditolak)

\begin{tabular}{cl}
\hline Aksi & Pengurus panti asuhan memilih menu \\
& Konfirmasi Kegiatan, kemudian pengurus \\
& mengkonfirmasi kegiatan dari user \\
& "amiami" dengan jenis kegiatan \\
& "syukuran" dan pada tanggal 24 \\
& November 2018, lalu klik tombol Tolak \\
\hline Ekspektasi & Data pendaftaran kegiatan pada panti \\
& asuhan Aisyiyah Cab. Ampang telah \\
& ditolak \\
\hline Hasil & Data pendaftaran kegiatan pada panti \\
& asuhan Aisyiyah Cab. Ampang telah \\
& ditolak \\
\hline Kesalahan & Tidak ada \\
\hline Pengujian & Sesuai dengan ekspektasi \\
\hline
\end{tabular}

select * from detail_keg where id_panti ='1

and id_keg $=$ ' 1 ' and usernm='amiami'

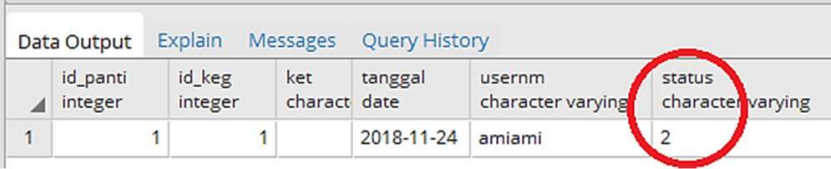

Gambar 11. Pengujian manual konfirmasi kegiatan (ditolak) pada database postgresql

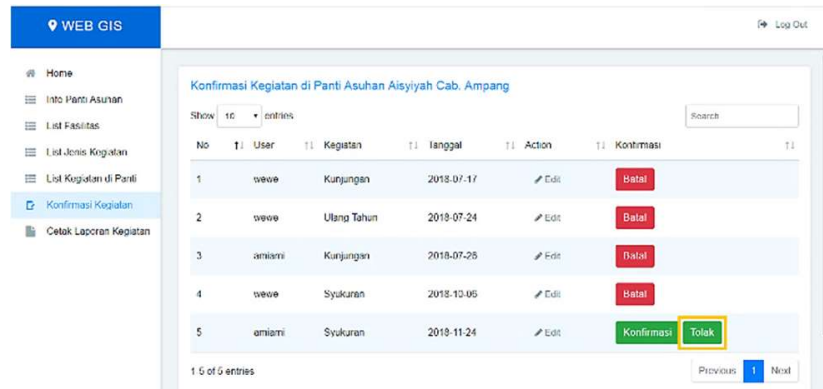

Gambar 12. Tampilan halaman konfirmasi kegiatan (ditolak)

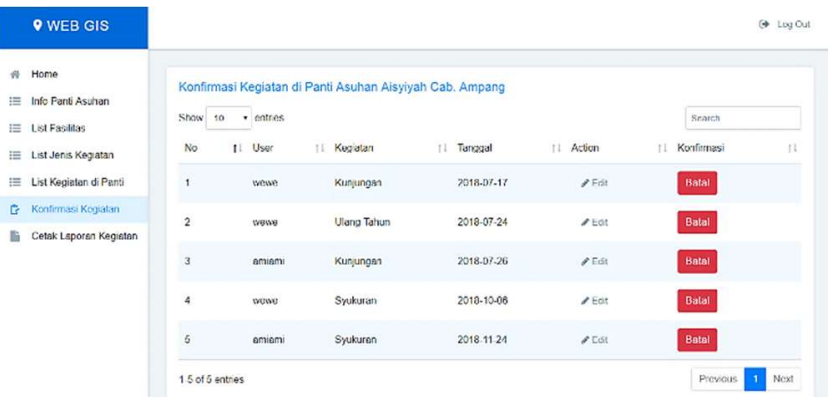

Gambar 13. Hasil pengujian konfirmasi kegiatan di panti asuhan

\section{Hasil Pengujian Seluruh Fungsional pada Sstem yang Dilakukan oleh Pengguna}

Berdasarkan implementasi dan pengujian yang telah dilakukan pada setiap fungsional, sistem pendaftaran kegiatan sosial pada panti asuhan di Kota Padang berbasis web gis yang dibangun sepenuhnya telah sesuai dengan rancangan yang dibuat. Implementasi basis data, user interface, dan program dilakukan sesuai dengan perancangan sistem. Semua fungsional telah diuji dengan menggunakan metode blackbox testing, hasilnya sesuai dengan rancangan, dan tidak ditemukan kesalahan saat diuji. Salah satu hasil dari pengujian sistem yang dilakukan oleh Sri Wahyuni dapat dilihat pada Gambar 14. 

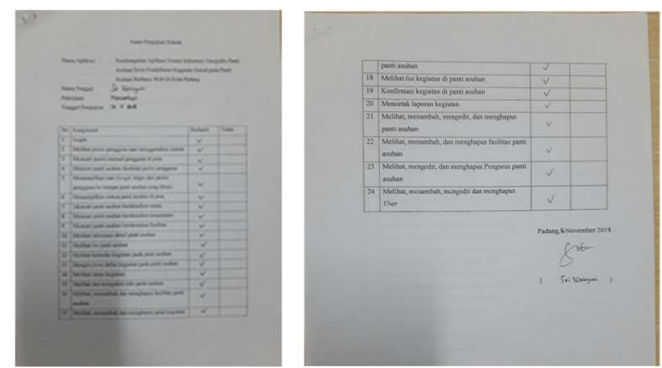

Gambar 14. Form pengujian sistem oleh Sri Wahyuni

Salah satu contoh buku kegiatan panti asuhan yaitu Panti Asuhan Wira Lisna dapat dilihat pada Gambar 15. Dan untuk perbandingannya dapat dilihat pada contoh laporan kegiatan yang bisa diunduh pada pemetaan panti sosial Kota Padanf dengan fitur pendaftaran aktivitas sosial yaitu pada Gambar 16 .

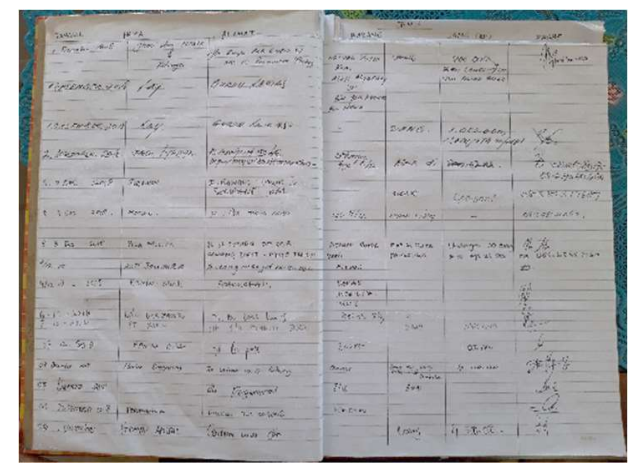

Gambar 15. Contoh buku kegiatan pada Panti Asuhan Wira Lisna

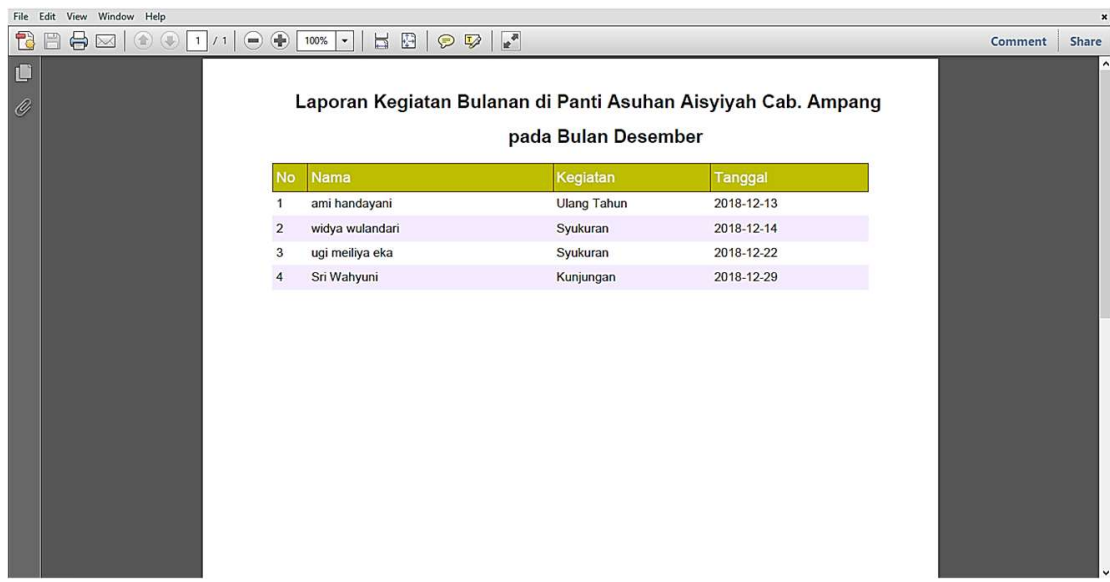

Gambar 16. Contoh Laporan pada Panti Asuhan Aisyiyah Cabang Ampang pada bulan Desember 2018

\section{KESIMPULAN}

Sistem informasi geografis panti asuhan serta pendaftaran kegiatan sosial berbasis web di Kota Padang telah dibangun dengan menggunakan metode waterfall analisis kebutuhan fungsional dirumuskan dari analisis proses, dokumen-dokumen wawancara dan penelitian terkait. Hasil dari analisis menghasilkan 14 fungsional dapat diakses oleh pengguna, 7 fungsional dapat diakses oleh pengurus panti asuhan, dan 5 fungsional dapat diakses oleh pengelola sistem. Sistem informasi geografis panti asuhan serta pendaftaran kegiatan sosial berbasis web di Kota Padang telah selesai dibangun dan dapat diakses pada alamat website https://panti-pdg.herokuapp.com. Pada pengujian yang telah dilakukan oleh lima pengguna terhadap sistem informasi geografis panti asuhan serta pendaftaran kegiatan sosial berbasis web di Kota Padang, diperoleh hasil bahwa sistem yang telah dibangun berjalan sesuai dengan rancangan yang dibuat.

\section{DAFTAR PUSTAKA}

[1] P. Panti Asuhan, Interviewee, Jenis-jenis kegiatan di panti asuhan. [Wawancara]. Juni 2018.

[2] Panti Asuhan, K. P., 2018. Proses Pendaftaran Kegiatan di Panti Asuhan [Wawancara] (Juni 2018).
[3] Heri, Zet. "Sistem Informasi Pemetaan Panti Asuhan Kota Semarang Berbasis Web", Sarjana, Universitas Dian Nurwastoro, 2011.

[4] Priyanto, Heri, and M. Azhar Irwansyah. "Rancang Bangun Aplikasi Sistem Informasi Majid, Panti Asuhan, Dan Pesantren Berbasis WeB." Jurnal Sistem dan Teknologi Informasi (JUSTIN) 4, no. 3: 410-414.

[5] Ariyani, Yossi Prima, Haris Suryamen, and Fajril Akbar. "Pencarian Kelompok Tani Menggunakan Sistem Informasi Geografis bagi Penyuluh di Kabupaten Agam." Jurnal Nasional Teknologi dan Sistem Informasi 3, no. 3 (2017): 334-342

[6] Fithriyyah, Ulfa, Fajril Akbar, and Haris Suryamen. "Pembangunan Sistem Informasi Sebaran Rumah Tangga Miskin Kelurahan Puhun Tembok Bukittinggi." SISFO Vol 6 No 16 (2016)..

[7] Afnarius, S., A. T. Putra, A. Tamara, U. G. S. Dinata, D. Ichwana, and F. Akbar. "Web GIS Development for Minangkabau Customary Village: A Case Study of Padang Lua Village, West Sumatra, Indonesia." International Journal of Geoinformatics 13, no. 4 (2017).

[8] Molchanova, Violetta S. "The use of online service booking in tourist activity." European Journal of Social and Human Sciences 2 (2014): 75-80

[9] Han, Sun Sheng, and Zhen Peng. "Public participation GIS (PPGIS) for town council management in Singapore." Environment and Planning B: Planning and Design 30, no. 1 (2003): 89-111. 
[10] Obeidavi, Zeinab, Kazem Rangzan, Mostafa Kabolizade, and Rouhollah Mirzaei. "A web-based GIS system for wildlife species: a case study from Khouzestan Province, Iran." Environmental Science and Pollution Research 26, no. 16 (2019): 1602616039.

[11] Hu, Yongtao, Ha Hang Ai, Mehmet Talat Odman, Ambarish Vaidyanathan, and Armistead G. Russell. "Development of a WebGIS-based analysis tool for human health protection from the impacts of prescribed fire smoke in southeastern USA." International journal of environmental research and public health 16, no. 11 (2019): 1981.

[12] Kerski, Joseph J., and Thomas R. Baker. "Infusing Educational Practice with Web GIS." In Geospatial Technologies in Geography Education, pp. 3-19. Springer, Cham, 2019.

[13] Sommerville, Ian. "Software engineering 9th Edition." ISBN-10137035152 (2011). 